\title{
POJAVNOST PSIHOAKTIVNIH TVARI U SREDNJOŠKOLSKE MLADEŽI
}

\author{
Marija Soča, Dragan Babić \\ Sveučilište u Mostaru, Filozofski fakultet, Odsjek Socijalnog rada, 88000 Mostar, Bosna i Hercegovina \\ Rad je primljen: 14.3.2015. Rad je revidiran: 28.3.2015. Rad je prihvaćen: 26.4.2015.
}

\section{SAŽETAK}

UVOD: Psihoaktivne tvari se počinju suprotstavljati normama društva, ali i državi već 50-ih godina prošloga stoljeća. Prije su bile zastupljene samo u odraslih osoba, dok je stanje danas alarmantnije tako da u psihoaktivnim tvarima sve više i češće uživaju i adolescenti. Cilj ovog istraživanja je ispitati pojavnost psihoaktivnih tvari u srednjoškolske mladeži.

ISPITANICI I METODE: Istraživanje se provodilo od 18. do 20. lipnja 2012. godine između učenika dviju mostarskih škola, Srednje Medicinske škole i Srednje Prometne škole. Ukupno je pristupilo 108 ispitanika oba spola. Za potrebe istraživanja korišten je ESPAD-ov upitnik.

REZULTATI: Ukupno 60\% učenika ispitivanog uzorka uzima psihoaktivne tvari. Cigarete puši ukupno 59\% učenika/ica Prometne škole, u odnosu na 48\% učenika/ica Medicinske škole. Mladež Medicinske škole od psihoaktivnih tvari najčešće uzima alkoholna pića u kombinaciji s tabletama. Srednjoškolska mladež koja koristi psihoaktivne tvari ima slabiji školski uspjeh, češće probleme s roditeljima te ulaze u spolne odnose bez zaštite.

ZAKLJUČAK: Statističke razlike o pojavnosti psihoaktivnih tvari u srednjoškolske mladeži nisu značajne. Učenici obje škole, statistički neznačajno, više uzimaju psihoaktivne tvari u odnosu na učenice. Mladež Prometne škole, u odnosu na mladež Medicinske škole, statistički neznačajno u nešto većoj mjeri puši više cigareta u danu. Statistički podatci su pokazali da su učenici/ice Prometne škole, naspram učenika/ica Medicinske škole, u nešto većoj mjeri uzimali ecstasy i marihuanu.

Ključne riječi: psihoaktivne tvari, adolescenti, obitelj, škola

Osoba za razmjenu informacija:

Soča Marija, magistar socijalnog rada

e-mail: marija1703@hotmail.com

\section{UVOD}

Pojam „droga” je poznat od davnina, njezina pojava zahvatila je Europu već nakon završetka križarskih ratova te otkrića Amerike. Iako je taj pojam dosta kompleksan u literaturama se najčešće definira kao: svaka supstancija prirodnog ili sintetičkog porijekla koja može izazvati ovisnost ili bar želju za ponovnim uzimanjem (1). Spominjanjem riječi „droga” odmah se usmjeravamo na glavni problem koji ona sadrži u sebi, a to je ovisnost o „drogi”. Baš kao i „droga” i taj pojam ima svoju određenu definiciju koja nam omogućava da što bolje shvatimo njihova značenja. Zbog toga se ovisnost o drogi najčešće definira: kao psihičko, katkada i fizičko, stanje koje nastupa uslijed međudjelovanja živog organizma i droge (1). Takvo stanje izaziva promjenu ponašanja kao i brojne druge reakcije koje nastaju povremenim ili trajnim uzimanjem psihoaktivnih tvari, a sve s ciljem da se postigne zadovoljstvo za kojim osoba teži ili se pak radi o ostvarivanju željenih psiholoških učinaka. Unutar društva osobe koje konzumiraju psihoaktivne tvari počinju se sve češće nazivati narkomanima. Riječ narkomanija dolazi od grčke riječi narko (ukočenost, pospanost) + manija (pretjerivanje, tjelesna zaokupljenost), a pod njome se misli na: bolesnu želju i neodoljivu potrebu za ponovnim uzimanjem određene psihoaktivne tvari, pri čemu se pojedinačna doza sve više povećava, a 
vremenski razmak od jedne do druge droge smanjuje (2). Gotovo svaki ovisnik ističe da pri konzumiranju psihoaktivne tvari doživljava prijatno letenje, osjećaj plutanja i da u tom svijetu sve izgleda tako lijepo. Netko se iz tog svijeta ne vrati nikada u realni svijet već nastavi sebe upropaštavati na najgori mogući način. Oni se odaju životu koji nisu u većini izabrali sami, već im ga je nametnulo društvo i upravo zbog želje da budu što bolje prihvaćeni oni se odaju psihoaktivnim tvarima s tim da većina mladeži ne zna koje su prave posljedice konzumiranja psihoaktivnih tvari. Imajući osjećaj letenja smatraju da njihovi problemi nestaju sami. Često pokušavamo dobiti odgovor na pitanje: Zašto mladež podliježe tom strašnom činu prihvaćajući da od svog života prave horor i da se zajedno s njim gube svaki put iznova? Mladež prolazi kroz razdoblje na prijelazu iz dječje dobi u odraslu dob, to razdoblje naziva se adolescencija, pubertet, buntovništvo te razdoblje bura i oluja. To je razdoblje u kojemu se događaju brojne promjene i upravo zbog toga zahtjeva veliku posvećenost osobito od strane roditelja i drugih autoriteta poput nastavnika. Većina roditelja ispočetka ne shvaća koje su potrebe njihove djece zbog čega se nerijetko javljaju sukobi unutar ovoga razdoblja. W. Glasser je u svojoj teoriji najjednostavnije prikazao koje su to potrebe, a među njih se ubrajaju: potreba za preživljavanjem - produživanjem vrste, potreba kao biološka kategorija i psihičke potrebe (3). U psihičke potrebe ubrajaju se: pripadanje - ljubav, moć, zabava i sloboda. Adolescencija donosi prekretnicu na pragu dječje i odrasle dobi. Prema brojnim istraživačima iz grane psihologije pretpubertet se javlja u različitom razdoblju kod oba spola. U djevojčica započinje s 9 ili 10 godina života i traje do 12-e ili 13-e godine života, dok u dječaka nastupa nešto kasnije, točnije s 13 ili 14 godina života i traje do 15-e ili 16-e godine života (4). Početak i trajanje puberteta ovisi o dva čimbenika:

1. unutarnjih čimbenika koji se odnose na genetske faktore i naslijeđe,

2. vanjskih čimbenika koji se odnose na prehranu, društveno - gospodarske prilike i stil života (4).

Promjene u pubertetu nastaju zbog podražaja hipofize na lučenje gonadotropnih hormona sa strane hipotalamusa i susjednih moždanih centara koji do tada nisu bili aktivni ili su bili ukočeni. Sve te promijene bude $u$ adolescentima osnovno pitanje: Tko sam i kuda idem? Posljedica takva pitanja je kontradikcija između prepoznavanja stvarnosti s neostvarenim željama, traženjem vlastitog identiteta i mjesta pod zlatnim Suncem, pripadanjem formalnim ili neformalnim grupama. Jedna od osnovnih pomisli je ta da je odrasli svijet dosadan i neprivlačan što dovodi do stvaranja bunta, tvrdoglavosti i do suprotstavljanja autoritetu. Unutar tih mladih života događaju se promjene za koje im je potrebna ruka roditelja i društva, ruka koja će im biti vodilja i uputiti ih što je dobro, a što ne. Najčešće se navode tri vrste promjena, a to su:

1. Intelektualne promjene naglašavaju da je pubertet završna faza razvoju inteligencije. Preduvjet za svaku intelektualnu aktivnost je emocionalna sigurnost.

2. Emocionalne promjene se najčešće manifestiraju na dva načina s jedne strane postoji osjetljivost, napetost, strah, a s druge strane se javlja tupost i zasićenost.

3. Promjene odnosa prema svijetu dovode do brojnih rizika. Zbog stvaranja idealne slike svijeta, koja se uvelike razlikuje od realne (roditeljske) slike, dolazi do sukoba između roditelja i djece (4).

Pošto je svaka od ovih promjena jako riskantna psiholozi daju osnovne smjernice roditeljima, ali i djeci.

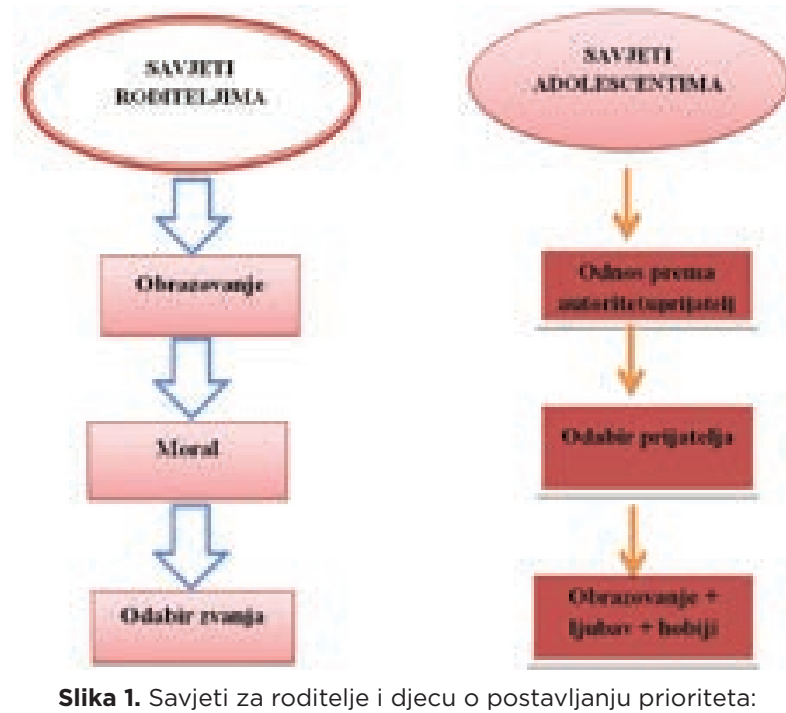


Adolescentno doba nosi u sebi velike teškoće i opasnosti za mladu osobu, ali joj istovremeno pruža niz mogućnosti za reorganizaciju u pravcu zdravlja te korigiranje pogrješaka iz ranijih razvojnih faza.

Cilj istraživanja je ispitati pojavnost psihoaktivnih tvari u srednjoškolske mladeži na području Mostara, Srednje medicinske škole Sestara milosrdnica i Srednje prometne škole Mostar.

\section{ISPITANICI I METODE}

Anketni upitnik o pojavnosti psihoaktivnih tvari u srednjoškolske mladeži proveden je u razdoblju od 18. do 20. lipnja 2012. godine u dvije srednje škole na području Mostara, Srednjoj medicinskoj školi Sestara milosrdnica i Srednjoj prometnoj školi Mostar među učenicima u dobi od 16-e do 17-e godine života koji pohađaju drugi i treći razred srednje škole. Anonimnoj anketi je pristupilo 108 učenika. Sudionici su se birali putem popisa učenika koji pohađaju navedene razrede. Naglasak je stavljen na etičke implikacije koje su se sastojale od nekoliko stavki, a to su:

- Usmeni pristanak ispitanika da pristupe anketi!

- Informiranje istraživačke skupine o anonimnosti ankete, povjerljivosti podataka!

- Upoznavanje ispitanika s ciljem i svrhom provedenog istraživanja!

- Ispitanicima je naglašeno da će se podatci koristiti u znanstvene svrhe (diplomski rad)!

- U dogovoru s ravnateljima obiju škola analiza podataka i donošenje zaključka će se dostaviti školama.

Ispunjavanje anonimne ankete je trajalo od 30 do 40 minuta. Nakon provedenog istraživanja slijedila je kvantitativna analiza s korištenjem objektivnih rezultata koji su prikupljeni standardiziranim mjernim instrumentom. Svi podatci su pretvoreni u brojčane vrijednosti koji su izraženi u postotcima.

Za statističku analizu rabljen je programski sustav SPSS for Windows (inačica 13.0., SPSS Inc, Chicago, Illinois, SAD) i Microsoft Excel (inačica 11.0., Microsoft Corporation, Redmond, WA, SAD). Svi statistički podatci su izraženi u postotcima koji su prikazani putem grafova i tablica, a izračunati su u programu Excel 2007. Na temelju dobivenih podataka slijedilo je analiziranje razlika u odgovorima srednjoškolske mladeži navedenih škola. Za razliku razdioba nominalnih i ordinalnih varijabli korišten je $\chi^{2}$-test, a pri manjku očekivanih frekvencija korištena je Yates-ova korekcija, kao i u određenim slučajevima spajanje susjednih ćelija zajedno. Razina značajnosti bila je pri $p \leq 0,05$. Čitava provedba ankete temeljena je na prigodnom uzroku. Za dobivanje podataka koristio se standardizirani upitnik Europsko istraživanje u školama o pušenju, pijenju i uzimanju droga (ESPAD) od ukupno 30 pitanja. S obzirom na analizu podataka provedena je eksploratora (ona koja teži istraživanju) i eksplanatorna anketa (ona koja teži objašnjavanju).

\section{REZULTATI}

U istraživanju je ukupno sudjelovalo 108 učenika iz dviju škola u dobi od 16-e do 17-e godine života oba spola, od čega je ukupno sudjelovalo 28 učenika muškog spola i 26 učenica iz Srednje prometne škole Mostar, dok je u Medicinskoj školi Sestara milosrdnica ukupno pristupilo 24 učenika i 30 učenica ( $\chi 2$ test $=0,858 ; \mathrm{p}=0,657$ ). Ukupno $59 \%$ srednjoškolske mladeži je bilo 1995 . godište, preostalih $41 \%$ su bili 1996.

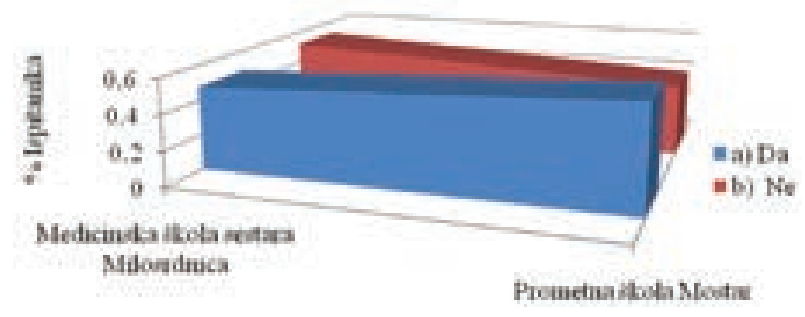

Slika 1. Pojavnost pušenja cigareta u srednjoškolske mladeži

Većina mladeži Prometne škole puši cigarete, ta stopa je jako velika i iznosi 59\% ( $\mathrm{N}=32)$. U odnosu na Prometnu školu ukupno 52\% $(\mathrm{N}=26)$ srednjoškolca Medicinske škole nisu pušači cigareta. Usporedbom rezultata pušenja cigareta između učenika Medicinske i Prometne škole nije dobivena statistički značajna razlika $\left(\chi^{2}\right.$-test $\left.=1,340 ; \mathrm{p}=0,246\right)$. 


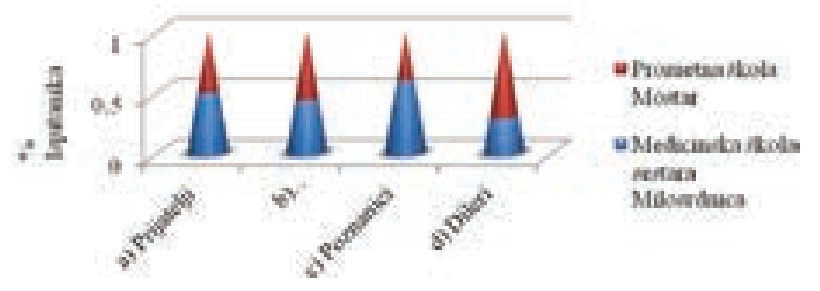

Slika 2. Raspodjela ispitanika prema tome tko im je prvi put ponudio psihoaktivne tvari

Srednjoškolcima su psihoaktivne tvari prvi puta u najvećem broju ponudili prijatelji, a najmanje dileri. Obradom rezultata nisu dobivene statističke razlike između dviju skupina $\left(\chi^{2}\right.$-test $\left.=2,036 ; p=0,564\right)$.

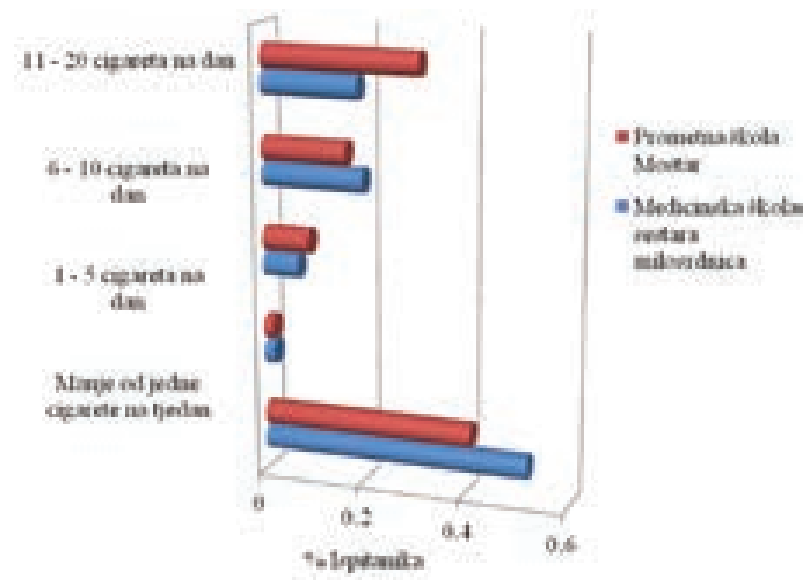

Slika 3. Raspodjela ispitanika u prema broju popušenih cigareta u posljednjih 30 dana

Odgovor uopće ne zauzima najviše postotaka, točnije u Prometnoj školi iznosi 41\% (N=22), a 52\% $(\mathrm{N}=28)$ u Medicinskoj školi. Najmanje postotaka iznosi odgovor manje od jedne cigarete na tjedan koji je zastupljen u jednakom omjeru u obje škole, točnije $2 \%(\mathrm{~N}=1 ; \mathrm{N}=1)$. Međutim, razlike o broju popušenih cigareta u posljednjih 30 dana s obzirom na školu koju učenici pohađaju nisu se pokazale statistički značajnim ( $\chi^{2}$-test $\left.=2,005 ; p=0,571\right)$.

Ukupno 78\% ( $\mathrm{N}=42)$ učenika Prometne škole i $60 \%(\mathrm{~N}=33)$ učenika Medicinske škole smatra da je najlakše nabaviti ljepilo za snifanje kao psihoaktivnu tvar, a najteže je nabaviti ecstasy. Iz dobivenih rezultata je moguće vidjeti da najviše statističke razlike imaju potpitanja o dostupnosti amfetamina ( $\chi 2$ test $=10,148 ; \mathrm{p}<0,017)$ i ecstasy-a $(\chi 2$-test $=31,216$; $\mathrm{p}<0,005)$. Statistička razlika nije značajna u odgovorima o dostupnosti sedativa ( $\chi 2$-test $=6,453$; $\mathrm{p}=0,092)$ i ljepila $(\chi 2$-test $=5,267 ; \mathrm{p}=0,072)$.
Većina učenika Medicinske i Prometne škole je konzumirala alkoholna pića u kombinaciji s tabletama od 3 do 5 puta u životu. Najmanje su konzumirali LSD, s tim da ta stopa u Medicinskoj školi iznosi 98\% (N=53) i 96\% (N=52) u Prometnoj. Statistička razlika među odgovorima nije značajna.

Odgovor od 3 do 5 puta je najviše zastupljen u argumentu Ozbiljne probleme s roditeljima, dok najmanje postotaka ima argument Slabiji uspjeh u školi koji u Medicinskoj školi iznosi 96\% (N=52) i 93\% (N=50) u Prometnoj školi. Među odgovorima ne postoji značajnija statistička razlika.

\section{RASPRAVA}

Kao što je već rečeno adolescencija je razdoblje bura i oluja. To je razdoblje u kojoj se mladež prvi put upoznaje s novim problemima. Jedan od takvih problema je nemogućnost izjednačavanja idealnog i realnog svijeta. Današnji mladi su sve više izloženi udisanju duhana što šteti njihovom organizmu i stvara rizik za njihovo zdravlje. Pitanje koje je jako značajno za ovo istraživanje glasi: Pušite li cigarete? To je jedno od pitanja gdje se stvara kontrast između dviju škola nad kojima je vršeno istraživanje. Većina mladeži Srednje prometne škole puši cigarete, ta stopa je jako velika i iznosi 59\% $(\mathrm{N}=32)$, dakle više od polovice mladih su izloženi duhanu tek ostatak, točnije $41 \%(\mathrm{~N}=22)$, nisu pušači cigareta. Dok, $s$ druge strane imamo potpuno drugačiju situaciju u Medicinskoj školi gdje većina mladeži nisu pušači cigareta ta stopa iznosi $52 \%(\mathrm{~N}=26)$, a preostalih $48 \%(\mathrm{~N}=28)$ su aktivni pušači. Prema ESPAD-ovom istraživanju, u Republici Hrvatskoj i drugim europskim zemljama, koje je provedeno u svibnju 2012. godine naglašava se porast trenda pušenja u Hrvatskoj za razliku od drugih ESPAD zemalja gdje taj trend stagnira ili opada (5). Svjetsko istraživanje o uporabi duhana u mladih (GYTS), provedeno u Hrvatskoj 2006. godine, među školskom djecom u dobi od 13 do 15 godina, ukazuje na veliku izloženost djece pasivnom pušenju (6).

Brojnim istraživanjima, koja su se provodila na temu Ovisnost o psihoaktivnim tvarima, došlo se do saznanja da su prijatelji upravo ti koji prvi puta ponude svojim vršnjacima cigarete ili druge 
Tablica 1. Raspodjela ispitanika o dostupnosti psihoaktivnih tvari

\begin{tabular}{ccccccccc}
\hline Odgovori & \multicolumn{2}{c}{ Amfetamini } & \multicolumn{2}{c}{ Sedativi } & \multicolumn{2}{c}{ Ecstasy } & \multicolumn{2}{c}{ Liepilo za snifanje } \\
\hline Nemoguć & $M$ & $P$ & $M$ & $P$ & $M$ & $P$ & $M$ & $P$ \\
& $11 \%(N=6)$ & $0 \%(N=0)$ & $0 \%(N=0)$ & $0 \%(N=0)$ & $13 \%(N=7)$ & $0 \%(N=0)$ & $0 \%(N=0)$ & $0 \%(N=0)$ \\
Vrlo teško & $42 \%(N=23)$ & $30 \%(N=16)$ & $7 \%(N=4)$ & $2 \%(N=1)$ & $28 \%(N=15)$ & $13 \%(N=7)$ & $0 \%(N=0)$ & $0 \%(N=0)$ \\
Prilično teško & $28 \%(N=15)$ & $46 \%(N=25)$ & $41 \%(N=22)$ & $46 \%(N=25)$ & $52 \%(N=28)$ & $34 \%(N=18)$ & $11 \%(N=6)$ & $2 \%(N=1)$ \\
Prilično lako & $19 \%(N=10)$ & $25 \%(N=13)$ & $43 \%(N=24)$ & $32 \%(N=17)$ & $4 \%(N=2)$ & $48 \%(N=26)$ & $28 \%(N=15)$ & $22 \%(N=11)$ \\
Vrlo lako & $0 \%(N=0)$ & $0 \%(N=0)$ & $4 \%(N=2)$ & $22 \%(N=11)$ & $0 \%(N=0)$ & $7 \%(N=3)$ & $60 \%(N=33)$ & $78 \%(N=42)$ \\
& $\div^{2}=10,148$ & & $\chi^{2}=6,453 ;$ & & $\div^{2}=31,216$ & & $\div 2=5,267$ & \\
& $p=0,017$ & & $p=0,092$ & & $p<0,005$ & & $p=0,072$ & \\
\hline
\end{tabular}

Tablica 2. Raspodjela ispitanika u odnosu na konzumiranje psihoaktivnih tvari

\begin{tabular}{ccccccccc}
\hline Odgovori & \multicolumn{2}{c}{ Sedativi } & \multicolumn{2}{c}{ Amfetamini } & \multicolumn{2}{c}{ LSD } & \multicolumn{2}{c}{$\begin{array}{c}\text { Alkoholna pí́a u kombinaciii s } \\
\text { tabletama }\end{array}$} \\
\hline \multirow{2}{*}{ 0 puta } & $M$ & $P$ & $M$ & $P$ & $M$ & $P$ & $M$ & $P$ \\
& $82 \%(N=42)$ & $84 \%(N=45)$ & $94 \%(N=51)$ & $91 \%(N=49)$ & $98 \%(N=53)$ & $96 \%(N=52)$ & $91 \%(N=49)$ & $80 \%(N=43)$ \\
1 - 2 puta & $23 \%(N=12)$ & $13 \%(N=7)$ & $5 \%(N=3)$ & $9 \%(N=5)$ & $2 \%(N=1)$ & $4 \%(N=2)$ & $7 \%(N=4)$ & $13 \%(N=7)$ \\
3 - 5 puta & $0 \%(N=0)$ & $2 \%(N=1)$ & $0 \%(N=0)$ & $0 \%(N=0)$ & $0 \%(N=0)$ & $0 \%(N=0)$ & $2 \%(N=1)$ & $7 \%(N=4)$ \\
& $\chi^{2}=3,419$ & $p=0,181$ & $\div^{2}=0,540$ & $p=0,462$ & $\div^{2}=0,343$ & $p=0,558$ & $\div^{2}=3,009$ & $p=0,222$ \\
\hline
\end{tabular}

Tablica 3. Raspodjela ispitanika u odnosu na neprilike koje su doživjeli u posljednjih 12 mjeseci zbog konzumiranja psihoaktivnih tvari

\begin{tabular}{|c|c|c|c|c|c|c|c|c|}
\hline Odgovori & & & $1-2$ & puta & & puta & $\chi^{2}$ & $\mathrm{p}$ \\
\hline Upustio/la se u spolne odnose & $\bar{M}$ & $p$ & M & $P$ & $M$ & $P$ & & \\
\hline bez zaštite & $93 \%(N=50)$ & $89 \%(N=48)$ & $5 \%(N=3)$ & $9 \%(N=5)$ & $2 \%(N=1)$ & $2 \%(N=1)$ & 0,541 & 0,763 \\
\hline Nesreću ili ozliedu & $98 \%(N=53)$ & $98 \%(N=53)$ & $2 \%(N=1)$ & $0 \%(N=0)$ & $0 \%(N=0)$ & $2 \%(N=1)$ & 2,000 & 0,368 \\
\hline $\begin{array}{l}\text { Ozbiline probleme s } \\
\text { roditelijma }\end{array}$ & $84 \%(N=45)$ & $72 \%(N=39)$ & $15 \%(N=8)$ & $23 \%(N=12)$ & $2 \%(N=1)$ & $5 \%(N=3)$ & 2,229 & 0,328 \\
\hline $\begin{array}{l}\text { Ozbiljne problemes } \\
\text { prijateljima }\end{array}$ & $93 \%(N=50)$ & $89 \%(N=48)$ & $7 \%(N=4)$ & $9 \%(N=5)$ & $0 \%(N=0)$ & $2 \%(N=1)$ & 1,152 & 0,562 \\
\hline Slabiii uspieh u školi & $96 \%(N=52)$ & $93 \%(N=50)$ & $4 \%(N=2)$ & $7 \%(N=4)$ & $0 \%(N=0)$ & $0 \%(N=0)$ & 0,706 & 0,401 \\
\hline
\end{tabular}

psihoaktivne tvari. Postotci u tom pitanju se jako malo razlikuju između dviju škola s tim da je odgovor prijatelj/ica najviše zastupljen u obje škole. $\mathrm{Na}$ osnovu toga može se reći da u najvećoj mjeri, neovisno o školi koju pohađaju, prvu cigaretu učenicima ponude prijatelji. U usporedbi s dobivenim rezultatima prema istraživanju koje su 2005. godine provele dr. med. spec. školske medicine Ljiljana i Smiljana Podrug na temu Ovisnost - budi jak nemoj početi! među učenicima od osmog razreda osnovne škole do četvrtog razreda srednje škole dobiveni su podatci prema kojima 52\% mladeži nitko nije ponudio cigaretama ili drugim psihoaktivnim tvarima, na drugom mjestu su to bili njihovi jako bliski prijatelji s $20 \%$, odgovor sam/a sam se odlučio/la probati je zastupljen u $16 \%$ mladeži, dok odgovor cura/dečko ima tek 5\% i na zadnjem mjestu se nalazi odgovor dileri s postotkom od 2\% (9). Uzmu li se u obzir dobiveni rezultati između dviju navedenih škola i rezultati dr. med. specijaliste školske medicine Smiljane i Ljiljane Podrug dolazi se do zaključka da u većini slučajeva mladeži psihoaktivne tvari ponude upravo njihovi prijatelji, dok na zadnjem mjestu se nalaze dileri.

U posljednjih 30 dana ukupno $52 \%(\mathrm{~N}=28)$ učenika Medicinske škole nije pušilo cigarete. No, suprotnost tom odgovoru je što u obje škole većina aktivnih pušača izjavljuje kako puši od 11 do 20 cigareta na dan. Taj postotak je značajno veći u Prometnoj školi gdje iznosi $31 \%(\mathrm{~N}=17)$. Pušenje je trend među srednjoškolcima koji je zastupljen kako u BiH tako i u drugim Europskim zemljama. Prema istraživanju 
ESPAD-a Hrvatska se 2012. godine nalazila treća na ljestvici po broju pušača sa čak $41 \%$. Najviše adolescenata pušača imaju Latvija, s čak $45 \%$ učenika muškog spola i $42 \%$ ženskog spola, te Češka. Stopa najmanje zastupljenosti adolescenata aktivnih pušača cigareta u 2012. godini su imali SAD-e, Island, Crna Gora, Albanija i Norveška. Djevojčice u mnogim zemljama prestižu dječake što je slučaj sa Češkom gdje zauzimaju 43\% (5).

Učenici obje škole najlakše mogu priskrbiti sebi ljepilo za snifanje, dok im je najteže za nabaviti ecstasy. Kada je riječ o konzumiranju sedativa, amfetamina, LSD-a i alkoholnih pića u kombinaciji s tabletama srednjoškolci dviju škola su od 1 do 2 puta najviše koristili sedative, a od 3 do 5 puta su konzumirali alkoholna pića u kombinaciji s tabletama. Ukupno 98\% ( $\mathrm{N}=53)$ učenika Medicinske škole i 96\% (N=52) učenika Prometne škole nisu konzumirali LSD. Prema ESPAD-ovom istraživanju Republika Hrvatska se nalazi ispod prosjeka u pogledu uzimanja sedativa među srednjoškolskom mladeži. Stopa uzimanja sedativa u Hrvatskoj je nešto veća u djevojčica gdje iznosi $6 \%$ za razliku od dječaka gdje je ta stopa 5\%. Od ESPAD zemalja najviše postotaka u uzimanju sedativa imaju Poljska ukupno 15\% i Monako s ukupnih 14\% (5). Istoimeno istraživanje naglašava da mladi koji rabe dvije ili više psihoaktivnih tvari imaju više problema s policijom, agresivniji su, češće se upuštaju u rizične seksualne odnose i više markiraju. Sve više je zastupljen trend da mladež konzumira alkoholna pića u kombinaciji s tabletama, rezultati su koje je u Hrvatskoj potvrdilo ESPAD-ovo istraživanje (10).

Većina mladeži koja je uzimala psihoaktivne tvari je doživjela neku neugodnu situaciju. Prema srednjoškolcima obje škole uzimanjem psihoaktivnih tvari najmanje su doživjeli nesreću ili ozljedu, a najviše, točnije od 3 do 5 puta, su doživjeli ozbiljne probleme s roditeljima. Od 1 do 2 puta srednjoškolci su imali ozbiljne probleme s prijateljima, slabiji uspjeh u školi te su se upuštali u spolne odnose bez zaštite. Istraživanjem na temu Zaštita reproduktivnog zdravlja mladih - modeli prevencije koje su 2008. godine objavili Dabo i suradnici došlo se do spoznaja da je spolni odnos pod utjecajem alkoholnih pića imalo barem jednom $62 \%$ ispitanika, dok je 11,9\% mladih imalo spolni odnos pod utjecajem psihoaktivne tvari (7). Ispitivanje dr. Dubravka Lepušića, koji posljednje četiri godine provodi besplatnu spolnu edukaciju po školama, pokazalo je da je $90 \%$ ispitanih učenika imalo rizičan spolni odnos. Njih tek $40 \%$ koristilo je zaštitu pri prvom odnosu, a $20 \%$ ne koristi nikakvu zaštitu $(7,9)$. Rezultati koji su objavljeni u medicinskom časopisu The Lancetsu zapanjujući. Oko dvjesto milijuna ljudi diljem svijeta ilegalno uživa „drogu”, što je svaka dvadeseta osoba od 15-e do 64-te godine. U studiji koju su proveli australski stručnjaci ocjenjuje se da je u 2009. u svijetu bilo između 149 i 271 milijuna ilegalnih korisnika marihuane, amfetamina, kokaina, heroina i morfija. Podatci Svjetske zdravstvene organizacije govore da zbog ilegalnog uzimanja „droga” u svijetu na godinu umre više od 250000 ljudi, od alkohola 2250 000, a od posljedica pušenja 5100000 (8).

\section{ZAKLJUČAK}

Statističke razlike o pojavnosti psihoaktivnih tvari između učenika/ica Prometne škole i Medicinske škole nisu značajne. Učenici obje škole, statistički neznačajno, više uzimaju psihoaktivne tvari u odnosu na učenice. Mladež Prometne škole, u odnosu na mladež Medicinske škole, statistički neznačajno u nešto većoj mjeri puši više cigareta $u$ danu. Mladeži Prometne i Medicinske škole „droga”je bila ponuđena i to najčešće od njihovih prijatelja/ica.

Ne postoje statističke razlike između učenika/ica Medicinske i Prometne škole u pogledu dostupnosti cigareta, marihuane, hašiša (kanabisa), sedativa i ljepila za snifanje.

\section{LITERATURA}

1. Ausfelder T. Jaki bez droge. Zagreb: Mozaik knjiga d.o.o.; 2004.

2. Cvjetković B. Psihoaktivne droge - zamke života. Split: LAUS; 1995.

3. Janković J. Obitelj u fokusu. Zagreb: etcetera d.o.o.; 2008.

4. Vasta R. i sur. Dječja psihologija. Zagreb: SLAP; 1997. 
5. Hrvatski zavod za javno zdravstvo (Internet). Dostupno na: www.hzjz.hr/publikacije/GYTS. pdf Posjećeno (06. kolovoza 2012.)

6. Hrvatski zavod za javno zdravstvo (Internet). Dostupno na: www.hzjz.hr/skolska/espad_2011. pdf Posjećeno (08. kolovoza 2012.)

7. Dabo J, Malatestinić Đ, Janković S, Bolf Malović $\mathrm{M}$, Kosanović V. Zaštita reproduktivnog zdravlja mladih - modeli prevencije. Medicina Fluminensis. $2008 ; 44: 1-74$.
8. Hrvatska radiotelevizija (Internet). Dostupno na: http://www.hrt.hr/index.php?id=48\&t=\&tx_ comments_pi1[page] $=4 \& \mathrm{tx} \_\mathrm{ttnews}[\mathrm{tt}$ news $]=146515 \& \mathrm{cHash}=\mathrm{b} 684 \mathrm{dfbcb} 1 \quad$ Posjećeno (20. kolovoza 2012.)

9. Greblo M, Šegregur J. Navika pušenja, konzumiranja alkohola i opojnih sredstava kod adolescenata. Hrvatski časopis za javno zdravstvo. 2011; 6:23-17.

10.Vujević E. Droga opća opasnost. Split: LUKANA; 1995.

\title{
PREVALENCE OF PSYCHOACTIVE SUBSTANCES IN SECONDARY SCHOOL YOUTHS
}

\author{
Marija Soča, Dragan Babić \\ University of Mostar, Faculty of Humanities, Department of Social Care, \\ 88000 Mostar, Bosnia and Herzegovina
}

\begin{abstract}
OBJECTIVE: Psychoactive substances are starting to oppose the norms of society, but also the state already in the 50s of the last century. Before, they were present only in adults, while today they have become an alarming situation, because they are more frequently enjoyed by adolescents. The goal of this study is to examine the prevalence of psychoactive substances in secondary school youths.

SUBJECTS AND METHODS: The study was carried out between June 18 and June 20, 2014, in two vocational schools in Mostar; Secondary Medical School and Secondary School of Transport. The subjects of this research were 108 students, both male and female. For the purposes of the research we used ESPAD's questionnaire.

RESULTS: The total of $60 \%$ of students takes psychoactive substances. 59\% of students from the Secondary School of Transport smoke cigarettes when compared to $48 \%$ of students from the Secondary Medical School. When it comes to the type of psychoactive substances, the adolescences from the Secondary Medical School usually take alcohol combined with pills. Due to the use of psychoactive substances secondary school students have lower academic achievement, problems with their parents, and are more likely to have unprotected intercourse.

CONCLUSION: Statistical differences on the incidence of psychoactive substances in secondary school youth are insignificant. Male students from both schools take more psychoactive substances than their female counterparts, but in insignificant percentages. Students from the Secondary School of Transport when compared to their peers from the Secondary Medical School smoke more cigarettes on a daily basis, but again statistically inconsiderable. Statistics have also shown that students from the Secondary School of Transport, when compared to their peers from the Secondary Medical School take more ecstasy and marihuana.
\end{abstract}

Key words: psychoactive substances, adolescents, family, school

Correspondence:

Soča Marija, Master of Social Work

e-mail: marija1703@hotmail.com 